日本臨床麻酔学会第 25 回大会シンポジウム

麻酔科医の果たすべき役割：周術期のニーズに応える麻酔

患者のニーズに応える麻酔導入法

鈴木昭広*

\begin{abstract}
[要旨] 手術室入室後, 麻酔導入で入眠するまでの過程で患者の二ーズを満たす方法 について検討した，吸入麻酔導入と静脈麻酔導入を比較したところ, 入眠に要する時 間は静脈麻酔導入が有意に短かったが, 導入時の合併症, 第三者による入眠時のフェ イススケール, 導入時の苦痛体験の自覚などに差はなかった．静脈穿刺困難な例など では血管確保に固執せす吸入麻酔導入を選択してもよいと考えられた．硬膜外穿刺を 鎮静下に行った試みでは, ミダゾラムをRamsay score III，IVを目標にタイトレー ションした群では穿刺自体の記憶がなく, 苦痛体験として自覚しない者が $90 \%$ を占 め, かつ疼痛反応は保たれて放散痛などの検出は可能であると考えられた.

キーワード : 麻酔導入法, 硬膜外麻酔, 患者の満足
\end{abstract}

（日臨麻会誌Vol.26 No.5, 483～488, 2006）

\section{はじめに}

手術直前, 麻酔導入で眠りに入る前の患者は麻酔 科医に何を求めているのだろうか？われわれは昨 年, 病棟搬出から手術室に入室するまでの過程にお いて, 患者の満足感を追求する入室方法として, 患 者の希望に応じて前投薬の有無・術前点滴の有無・ 入室方法や衣服を自由選択させる，いわばテーラー メイド入室を行った結果, 患者の満足感が向上する 結果を得た ${ }^{1)}$.

そこで今回, 患者が手術室に入室してからの苦痛 を取り除く試みとして，麻酔導入方法および，麻酔 導入前の苦痛体験である硬膜外穿刺を快適にする方 法の比較を行い, 患者のニーズに応える導入とは何 かについて考えてみた。 なお, 以下に紹介する臨床
調査はいずれも各協力施設内で患者の同意を得て行 われている。

\section{Iどの麻酔導入方法が患者にとって快適か？}

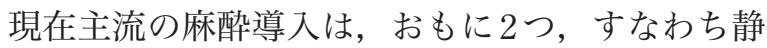
脈麻酔薬による導入と吸入麻酔薬による導入であ る，前者では血管痛が，後者では「におい」が不快 体験を生じうる。しかし，患者自身にいずれの導入 を望むかを尋ねても，患者は導入に関する十分な知 識をもち合わせておらず，以前に全身麻酔を経験し ている場合を除き，希望をとることは難しい．また， 患者の観点から見ていずれの方法が快適かを検討し た報告もない．結局，麻酔導入法は麻酔を担当する 者の「好み」や「経験」に左右されている感が否め ない。 そこで, 吸入麻酔導入と静脈麻酔導入とを比
著者連絡先 鈴木昭広

产 078-8510 旭川市緑が丘東 2条1-1-1 旭川医科大学麻酔・蘇生学講座 
表 1 吸入麻酔導入と静脈麻酔導入との比較結果

\begin{tabular}{|c|c|c|c|}
\hline & Sevoflurane 群 $\mathrm{N}=51$ & Propofol 群 $\mathrm{N}=56$ & 有意差 \\
\hline ASA1/2 & $27 / 24$ & $26 / 30$ & ns \\
\hline 年齢(yrs) & $51 \pm 16$ & $56 \pm 15$ & ns \\
\hline 身長 $(\mathrm{cm})$ & $158 \pm 10$ & $158 \pm 10$ & ns \\
\hline 体重 $(\mathrm{kg})$ & $59 \pm 14$ & $59 \pm 11$ & ns \\
\hline 入眠所要時間 (sec) & $101 \pm 50$ & $51 \pm 20$ & $p<0.01$ \\
\hline 導入時フェイススケール (mm) & $7 \pm 12$ & $9 \pm 17$ & ns \\
\hline 合併症＜wide>咳 & 2例 & 2例 & ns \\
\hline 換気困難 & 8 例 & 3例 & ns \\
\hline 上気道閉塞 & 6 例 & 4例 & ns \\
\hline 頻呼吸 & 1 例 & 0例 & ns \\
\hline 体動 & 5 例 & 9例 & ns \\
\hline 分泌物増加 & 2例 & 1例 & ns \\
\hline 多弁, 呂律困難 & 1 例 & 3例 & ns \\
\hline $\begin{array}{c}\text { 導入の快適さ } \\
\text { （苦痛・不快ありと答えた人数） }\end{array}$ & $20 \%(10 / 51)$ & $36 \%(20 / 56)$ & ns \\
\hline $\begin{array}{c}\text { 次回の麻酔導入の希望 } \\
\text { (次回も同じ方法を希望した人数) }\end{array}$ & $92 \%(47 / 51)$ & $91 \%(51 / 56)$ & ns \\
\hline
\end{tabular}

導入時間以外は両群で差がなかった。

較することにした。

ASA 分類 1 〜 の定期手術患者を対象とし，フェ ンタニル $1 \mu \mathrm{g} / \mathrm{kg}$ 投与後, 脳内濃度がピークを迎え る 4 分後に酸素, 亜酸化窒素 $(66 \%)$, セボフルラン $5 \%$ で通常呼吸導入を行う群と, プロポフォール(丸 石製薬） $2 \mathrm{mg} / \mathrm{kg}$ を投与する群に無作為に振り分け た。薬物投与開始から睫毛反射消失までの時間を入 眠所要時間とし，そのときの患者の表情を看護師に 評価させ, 導入に伴う合併症を調査した。術後, 患 者自身に聞き取り調査を行い, 導入時に何か苦痛や 不快を感じたか, また次回麻酔を受けるときに今回 と同じ方法で入眠したいかを尋ねた。

結果を表 1 に示す。患者のプロフィールに差はな く, 導入所要時間は有意にプロポフォール群で短か つたが，導入時合併症，導入時のフェイススケール に差はなかった。導入時の苦痛・不快の有無にも大 きな差はなく, 次回麻酔希望は両群とも $90 \%$ 以上 が同じ方法でよいと答えた。

この結果より, 患者にとっては麻酔の導入方法は
静脈麻酔でも吸入麻酔でも大差はないことがわか る。導入方法に固執せず，例えば点滴がとりにくい 場合には吸入麻酔導入で対応するなど，臨機応変に 苦痛の少ない方法をとることが患者のニーズに応え る麻酔ではないかと考えられた。

\section{II 導入前の不快体験： 硬膜外穿刺を快適にするには？}

麻酔導入の直前に硬膜外麻酔が行われることも多 いが，穿刺の体験は術後に患者が想起する不快な経 験となっている。そこで，ニーズに応える麻酔導入 の一環として，硬膜外穿刺を快適に行う方法につい ても検討した。

ASA 分類 1 ～20定期手術患者を対象とし，フエ ンタニル $1 \mu \mathrm{g} / \mathrm{kg}$ 投与後, 脳内濃度がピークを迎え る 4 分後から硬膜外穿刺を行う群と, ミダゾラムを Ramsay score III（言語刺激に応答する）～IV（入眠し ているが刺激に反応する)で維持するように投与し， 硬膜外穿刺を行う群とを比較し，穿刺時のフェイス 
表2 鎮静下硬膜外穿刺方法の比較結果

\begin{tabular}{|c|c|c|c|}
\hline & Fentanyl 群 $\mathrm{N}=74$ & Midazolam 群 $\mathrm{N}=80$ & 有意差 \\
\hline ASA1/2 & $39 / 35$ & $41 / 39$ & ns \\
\hline 年齢 (yrs) & $57 \pm 16$ & $54 \pm 15$ & ns \\
\hline 身長 (cm) & $158 \pm 9$ & $158 \pm 9$ & ns \\
\hline 体重 (kg) & $58 \pm 11$ & $56 \pm 11$ & ns \\
\hline 薬物使用量 & $1 \mu \mathrm{g} / \mathrm{kg}$ & $2.9 \pm 1.2 \mathrm{mg}(1 \sim 6.5 \mathrm{mg})$ & - \\
\hline 穿刺時記憶あり & $84 \%(62 / 74)$ & $6 \%(5 / 80)$ & $p<0.01$ \\
\hline 穿刺時フェイススケール(mm) & $18 \pm 21$ & $19 \pm 20$ & ns \\
\hline 穿刺時 $\mathrm{SpO}_{2}$ 低下 (<95\%) & 43例 & 47例 & ns \\
\hline 穿刺中の体動 & $26 \%(19 / 74)$ & $25 \%(20 / 80)$ & ns \\
\hline $\begin{array}{c}\text { 穿刺の快適さ } \\
\text { （苦痛・不快ありと答えた人数） }\end{array}$ & $41 \%(30 / 74)$ & $6 \%(5 / 80)$ & ns \\
\hline $\begin{array}{c}\text { 次回硬膜外穿刺時の希望 } \\
\text { (次回も同じ方法を希望した人数) }\end{array}$ & $84 \%(62 / 74)$ & $95 \%(76 / 80)$ & ns \\
\hline $\begin{array}{c}\text { チューブ留置後のテストドーズ判定 } \\
\text { (判定が時に困難と答えた人数) }\end{array}$ & $0 \%(0 / 74)$ & $11 \%(9 / 80)$ & ns \\
\hline
\end{tabular}

穿刺時記憶の忘却率はミダゾラム群で有意に高かった。

スケール・体動の有無・穿刺時合併症 - 麻酔科医に よる安全性の評価を行い, 術後の聞き取りで穿刺時 の記憶・穿刺時の苦痛の有無・また次回硬膜外穿刺 を受けるときに今回と同じ方法での穿刺を希望する かどうかを調査した。

結果を表 2 に示す。穿刺時の記憶はミダゾラム群 で有意にない者が多かったが，全員が忘れていたわ けではなく，記憶のあった者は全員が穿刺になんら かの不快感を自覚していた。穿刺時の看護師による フェイススケール評価では疼痛強度に差は認めなか った。患者が苦痛を感じた頻度は, 両群とも穿刺中 に $\mathrm{SpO}_{2}$ の低下を認めた者があったが頻度には差が なかった，穿刺は側臥位であり $\mathrm{SpO}_{2}<95$ 未満の低 下に対しては酸素投与のみで対応が可能であった。 穿刺中に体動を認めた頻度は差がなく，針が抜ける ほどの危険な体動はなかった，鎮静により，ミダゾ ラム群の $11 \%$ の症例で麻酔科医がチューブ留置後 のテストドーズ判定の際に強い呼びかけを行わない と困難であると感じていた，両群とも患者の $80 \%$ 以上が次回の硬膜外穿刺時に同じ方法での穿刺を希 望した。
参考までに，全身麻酔下で硬膜外穿刺を行えば患 者は一切の記憶がなく好ましいように思えるが，公 式には受け入れられない印象がある. Horlockerら は 4,000例の硬膜外穿刺を全身麻酔下に安全に実施 できたという報告を行っているが ${ }^{2)}$ ，神経損傷の頻 度に比して調査症例数が少ないこと, その後脊髄損 傷の症例報告 ${ }^{3)}$ などもあり，揭載誌の Editorialでは 強固な批判姿勢を打ち出し ${ }^{4)}$, 5), 小児 ${ }^{6)} や$ 外傷 $^{7)}$ な゙ の事例を除き，少なくとも放散痛を検出できない状 況下での穿刺を行うべきではないという意見が強 ( ${ }^{8)}$.その意味ではミダゾラム鎮静下では疼痛反応 は保たれ，放散痛を検出できると考えられた。

以上より，ミダゾラムで鎮静する群では硬膜外穿 刺を $90 \%$ 以上が忘れており不快体験として認識す る率が低く，かつ疼痛反応は保たれており有用と考 えられた。

\section{III この取り組みで患者のニーズは 満たされているのか?}

今回の 2 つの取り組みの結果感じる印象として は, 導入調査, 硬膜外穿刺調査いずれの取り組みで 


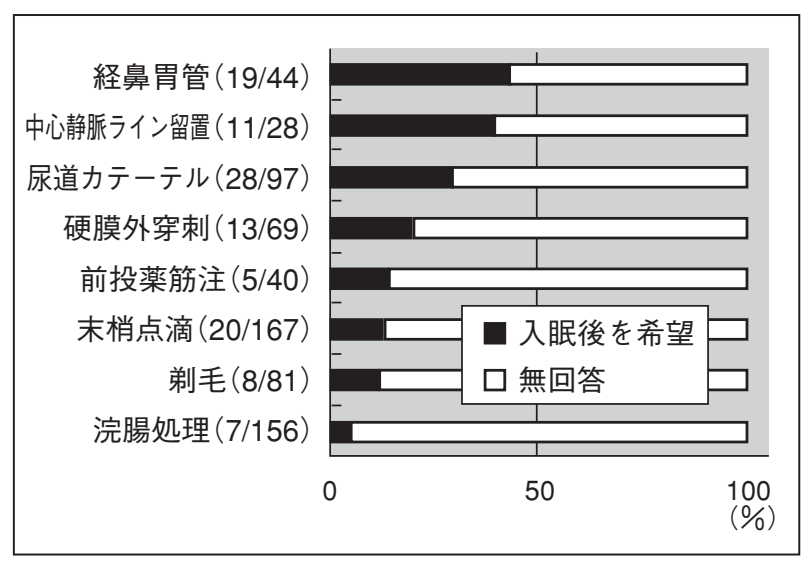

図1 導入前の患者の苦痛・不快体験アンケート結果 可能なら入眠後に行ってほしい導入前の苦痛体験のア ンケート調查結果. 比率の高い順に示した。

も，患者はなんらかの苦痛や不快を感じているにも かかわらず，結果的に「次回も同じ方法でよい」と 答える割合が高いということである。比較した $2 つ$ の方法が質的に同じ意味をもち, かつ今回の取り組 み内容が評価された，と解釈できないこともないが, それだけではないのではなかろうか？以前行われ た鎮静下の硬膜外穿刺の調査でも, 同じく $90 \%$ 近 くが満足しているという結果が得られている ${ }^{9)}$.

つまり，高い満足感の背景には，「実際の満足」 というよりも, 代替手段に関する経験, 知識の欠如 や，麻酔の工夫に関する無関心もあるのではないか と考えられた。

\section{IV 患者の思考回路は「事なかれ主義」と「減点法」}

患者が術後に想起する手術体験としては，「苦痛， 不快があり二度としたくない」「苦痛，不快はある が無事終わり満足」「苦痛, 不快がなく満足」「快適 でまた受けたい」の4つのパターンがありうる。し かし, 現実には手術や麻酔を「また受けたい」と思 う人はおらず，「苦痛，不快がなく満足である」こ とが患者の望むゴールとなろう。その意味で, 患者 の思考回路は「事なかれ主義」であるといえる. 広 辞苑によれば「事なかれ主義」とは“ひたすら何事 も起こらず無事ばかりを望む消極的なやり方”とさ
れる ${ }^{10)}$.つまり，患者は無事に手術が終わりさえす れば多少のことは気にしないものであり,「(今回無 事に済んだから)次回も同じ方法でよい」という回 答の背景になった可能性は否めない.

また，患者はおそらく「減点法」の思考回路もも っていると考えられる。手術や麻酔に対して不安は あるものの，根底には「何もなくて当たり前」とい う感覚があるのではないだろうか. その結果, 何か 自分にとって良かったと思うことに対する満足 (加 点)よりも, 不満, 不快を感じることに対する印象 (減点)が強まると考えられる。したがって，今回の 試みのように不快をなくすような努力を行うことは 重要と考える.

\section{$\mathrm{V}$ 患者の感じる苦痛・不快のもとは何か？}

患者の思考回路から，少なくとも苦痛，不快は可 能なかぎり排除することが重要であることが推察さ れたため, 導入までに必要とされている各種の処置 のいずれが患者に苦痛・不快感情を抱かせるかにつ いてアンケート調査を実施した。結果を図 1 に示す。

苦痛，不快があり可能なら麻酔後に行ってほしい 導入前の処置としては経鼻胃管, 中心静脈カテーテ ル，尿道カテーテルの留置が上位を占めた。この結 果から, 処置時に苦痛があり, その後の苦痛の時間 が長いものほど患者には敬遠される様子が見てとれ る。おそらくは長い苦痛体験の時間が不快な記憶を 強化するためと考えられる。逆にいうと，麻酔導入 時の苦痛・不快体験は苦痛を感じる時間が短く, 患 者にとっては麻酔科医が考えているほど重要なニー ズにはなりにくい可能性がある.

\section{VI 患者の二ーズは多彩}

アンケートの自由記載欄には，導入までの過程で 患者が感じたさまざまなニーズが述べられていた。 「眠りにつくときに医師と看護師が雑談をしている. これからの処置などを今一度説明するなどの時間と してほしい」「気分を落ち着かせるための音楽を流 
してほしい」「頻回なベッドの乗り換えが煩雑，な んとかならないか?」. また，術前の説明に関して も「点滴を含めたそれぞれの処置が何のために必要 なのか詳しく教えてほしい」という者もいれば, 「麻酔の死亡リスクが 5 万人に 1 人などという話はし てほしくなかった」「手術が終わったら全然大した ことはなくこんなものかと感じた. リスク云々で不 安を煽るより，心配ないということを強調してほし かった」などがあった。

つまり，麻酔の手技的なことのみならず，患者と の導入直前までのコミュニケーション，個々の患者 に応じたインフォームドコンセントも重要なニーズ であることが示唆される。

\section{VII 手術は旅行, 麻酔科医はパイロット}

今回の調査を通じて，手術と旅行の類似点を感じ た。例えば海外旅行する場合，人は旅行代理店で旅 のプランを練り，飛行機に乗って現地に飛び，機内 では添乗員，そしてパイロットやアテンダントとの 交流がある。目的地では現地ガイド，添乗員ととも に観光地を巡る。旅行後に思い出すのはおもに現地 での出来事であり, なかには添乗員や現地ガイドの こと, 旅行代理店の空口担当者を覚えている人もい るだろうが，パイロットやアテンダントのことを覚 えている人はほとんどいないであろう。フライトが 無事に済めば特に印象はなく，逆に摇孔が激しかっ た場合などは強烈な記憶が残ってしまう。

手術という患者の人生の一大イベントのなかで, 麻酔科医は患者を手術前の世界から手術後の世界に 連れて行くパイロットのようなものである。患者か ら求められているのは安定した麻酔管理と, 苦痛, 不快のない周術期体験である。しかも，われわれが 一番苦労している時間に患者は麻酔下にあり意識が ない．ただ，飛行機のパイロットと異なる点は術前 と術後に患者とかかわる機会がもてる点であり，こ の時間を利用してお互いの理解を深めることはでき る. 術前, 術後のコミュニケーションは患者のニー
ズを確認するための貴重な機会でもあり，有効に活 用すべきである。

麻酔導入のイベントは，いわば飛行機の離陸の瞬 間である，今回の一連の試み自体は患者の苦痛・不 快を少しでも少なくするために必要な事項ではある が，パイロットだけが頑張っても，また離陸の瞬間 だけを頑張っても意味がないのと同じく，これだけ ではニーズに応えるには不十分で，求められている ニーズのごく一部を満たしたに過ぎないといえる。 真に患者のニーズに応えるためには，導入までのす べての過程において，麻酔科医以外のスタッフも含 めて患者の不快体験をなくしていくことが必要と考 える。

謝辞 本シンポジウムでの発表にあたり調査にご協 力いただいた，北海道がんセンターの松野賢一先生， 函館五稜郭病院の平井裕康先生，釧路赤十字病院の 阿部展子先生に感謝いたします。

\section{参考文献}

1）鈴木昭広，平井裕康，岩波悦勝ほか：患者が選ぶ入室 までのプロセス一前投薬・輸液・移動方式のオーダーメ イド入室の試み一。 日臨麻会誌 $26 ： 57-65,2006$

2) Horlocker TT, Abel MD, Messick JM Jr, et al.: Small risk of serious neurologic complications related to lumbar epidural catheter placement in anesthetized patients. Anesth Analg 96: 1547-1552, 2003

3) Kao MC, Tsai SK, Tsou MY, et al.: Paraplegia after delayed detection of inadvertent spinal cord injury during thoracic epidural catheterization in an anesthetized elderly patient. Anesth Analg 99: 580-583, 2004

4) Rosenquist RW, Birnbach DJ : Epidural insertion in anesthetized adults: will your patients thank you? Anesth Analg 96: 1545-1546, 2003

5) Drasner $\mathrm{K}$ : Thoracic epidural anesthesia: asleep at the wheal? Anesth Analg 99: 578-579, 2004

6) Krane EJ, Dalens BJ, Murat I, et al.: The safety of epidurals placed during general anesthesia. Reg Anesth Pain Med 23: 433-438, 1998

7) Dutton RP, Boehm C, Shere-Wolfe R, et al.: Epidural 
catheter placement may also benefit intubated and sedated patients. Anesth Analg 98: 875, 2004

8) Bromage PR, Benumof JL: Paraplegia following intracord injection during attempted epidural anesthesia under general anesthesia. Reg Anesth Pain Med 23:
104-107, 1998

9) Kasaba $\mathrm{T}$ : The effects of small dose midazolam in patients to reduce the uncomfortable feeling during epidural block procedure. Masui 43: 547-550, 1994

10）新村出編：広辞苑 第五版. 岩波書店, 1998

\title{
Patient Discomfort Just Before Induction : What Can the Anesthesiologist Do?
}

\author{
Akihiro SUZUKI \\ Department of Anesthesiology and Critical Care Medicine, Asahikawa Medical College
}

What can the anesthesiologist do for the patient to minimize discomfort just before induction of general anesthesia? Two major concerns which may compromise patient satisfaction were studied.

First, we compared the induction profile between intravenously administered propofol and tidal breathing induction with $5 \%$ sevoflurane and $66 \%$ nitrous oxide. Induction time was significantly longer in the Sevo group, however, complication, patient discomfort, and facial scale evaluated by attended nurse were not different from the Propofol group. Thus, sevoflurane induction can be a suitable option if a vein is difficult to access.

Second, patient discomfort during epidural tube insertion under sedation with midazolam or fentanyl were compared. When midazolam was administered to achieve a Ramsay sedation score of III to IV, $90 \%$ of the patients forgot the epidural catheterization procedure itself, but were able to address pain or abnormal sensations. Therefore, midazolam should be chosen if the patient is anxious about the procedure.

Key Words : Induction of general anesthesia, Epidural anesthesia, Patient satisfaction 